\title{
Ahlak, Siyaset ve Demokrasi Bağlamında Kötülük ve Şiddet
}

\author{
Yaylagül Ceran Karataş
}

\begin{abstract}
Öz: Çalışmamızda ilk olarak, kötülüğün ve şiddetin insan doğasına içkinliği ve fakat aynı zamanda aşkınlığı iddiaları ahlak ve siyaset alanlarından hareketle ele alınacaktır. Ardından insanın doğasının yanı sıra eylemlerinin aracı olarak kabul edilen kötülük ve şiddetin varlık koşullarını, doğasını, kaynağını ve tarihteki rolünü Kıta Avrupası’nda15. yüzyıldan 21. yüzyıla kadar gelen kırılma noktaları bağlamında inceleyeceğiz. Özellikle "günümüzde yüz yüze kalınan ve 'belirli bir tür' demokrasinin ihdası için işlenen şiddet ve kötülük, insanın özgürleşme sürecinde nasıl bir role sahiptir?" sorusu çerçevesinde siyaset ve ahlak alanlarından hareketle şiddetin-kötülüğün durumunu Arendt'in, Benjamin'in şiddet eleştirileri, Keane'nin kategorileri çerçevesinde ele alacağı. Çağımızda mevcut şekliyle şiddet alanı hem kötülüğün apaçıklığını hem de siyasetin yasalılığını içeren diyalektik bir alandır. Balibar’ın ifadesiyle, şiddet alanı tahayyül edilebilir, aynı zamanda akılcı biçimde sınırlanmış bir kötülük imparatorluğu olmasaydı, siyaset de nomos'un imparatorluğu olmazdı. Sonuçta ise kötülük ve şiddetle ortaya çıkan sorunların demokrasiyle ilişkisi üzerinden demokrasinin ne kadar demokratik olunup olunmadığından bağımsız olarak topluma ve bireylere ne kadar var olma imkânı yarattığına göre değerlendirilmesi gerektiği; demokrasinin şiddeti-kötülüğü paranteze alarak değil onları rehabilite ederek inşa edildiğinde yüzyılımızda karşılaşılan sorunların kısmen çözüme ulaştırılabileceği yargıları üzerinde duracağız.
\end{abstract}

Anahtar Kelimler: İnsan Doğası, Adalet, Kötülük, Şiddet, Demokrasi, Hukuk, Ahlak.

Abstract: In this article, we will discuss human nature and acts with regard to evil, violence, and democracy and whether they are inherent to our nature or not on ethics and political grounds. Then we follow the question which is "what kind of roles evil and violence have in the liberation of the human being?" Following on from that, we will inquire into evil and violence under the umbrella of disputed "particular democracy" on the grounds of epistemology, ethics, historical roles, and nature in the 15th and 21st century in Continental Europe. First of all, we consider that evil and violence are the instruments which are legitimized via democracy, how we can correlate ethics, politics, and democracy. In other words, what is the role of evil and violence in history? Then within this context, how we can define democracy, evil, and violence in relation to ethics and politics? While researching these questions, we will follow Arendt's and Benjamin's critics of violence and also categorize evil and violence using Keane's arguments. Our argument is that there is a way which we can find in non violent resistance within a new understanding of democracy in the public ethics and politics.

Keywords: Human Nature, Justice, Evil, Violence, Democracy, Ethics, Law.

(C) İlmi Etüdler Derneği

DOI: 10.12658/human.society.7.14.M0214

İnsan \& Toplum, 7(2), 2017, 113-140.

insanvetoplum.org
Başvuru: 17.06.2017

Revizyon: 30.08.2017

Kabul: 21.11.2017

Basım: 15.12.2017 


\section{Giriş: Kötülüğün ve Şiddetin Ontolojisi}

Felsefe tarihi insanın, bir birey ve kişi olarak ahlak ve siyaset zemininde iyi-kötü, suç-ceza, adalet-zulüm gibi ikilikler bağlamında kendi varlığına dair sorgulamalarının ve arayışlarının bir panoramasını sunar. Aristoteles'in "insan politik bir hayvandır" (zoon politikon) ve Hobbes'un "insan insanın kurdudur" (homo homini lupus) yargılarında temellenen ve 21. yüzyıla kadar Aydınlanmanın iktidarında somutlaşan "insan doğasının rasyonel mükemmelliği ile içgüdüsel saldırganlığı" arasındaki karşıtlıkla birlikte kötülük ve şiddet ahlakın ve siyasetin problemi ve dahi aracı olmuştur. Bu noktada baskı, korkutma, sindirme, öldürme, savaş, suç ve cezalandırma, başkaldırı, isyan, intihar vb. eylemler hem öznesi hem de nesnesi açısından ahlakın ve siyasetin karşısında çözüm bekleyen olgular olarak durmaktadır. Kötülüğün ve şiddetin bir yandan demokrasinin eliyle kendisine meşruiyet alanları kuran bir araç bir yandan da simgeleştirilmeleriyle sosyal ilişkilerde içkin ve yıkıcı bir nitelik oldukları kabul edilirse iktidar ve demokrasiyle bağları nasıl inşa edilmiştir-edilmelidir? Bir başka ifadeyle, tarihte kötülük ve şiddetin rolü nedir? $\mathrm{Bu}$ çerçevede demokrasi, kötülük, şiddet ve iktidar ahlakın ve siyasetin problemi olarak nasıl tanımlanmıştır? Bu gibi soruları cevaplayabilmek için kötülügün ve şiddetin ontolojisini incelememiz gerekmektedir.

21. yüzyıl öznenin tanrıya, devlete ve doğayı yöneten "aydınlanmacı, mekanikleştirici akla” olan güveninin ve her türlü sınırlandırıcı-sınıflandırıcı teorik çerçevelerin yıkılış çağıdır. Aslında başka bir ifadeyle, her türlü teorik inşanın sonuna yönelik çağrıların yüzyılıdır. Bu yüzyılda tarihin sonu, ideolojilerin sonu, felsefelerin sonu ve öznenin sonu (ölümü) gibi tezlerin doğrultusunda, insanlık için ahlaki anlamda da bir çeşit "sıfır noktası", tüketilmişlik yaşanmaktadır. Burada Batı eksenli ortaya çıkan bu dönüşümler ve tüketilmişlik adı altında sergilenen "küresel oyun" Davutoğlu'nun beş bunalım sınıflaması altında belirlediği noktalardan hareketle ele alındığında insanlık ölçeğinde yaşanan bu sorunların ana kesişim alanlarının siyaset ve ahlak olduğu görülebilmektedir. Ona göre yaşanan bu dönüşümlerin açıklanabilmesi ve üzerinde konuşulabilmesi için bu beş bunalım noktasının iyi açımlanması gerekmektedir:

21. yüzyılda Batı bir dönüşüm yaşamaktadır, bu dönüşümler beş bunalım noktasından hareketle açıklanabilir. İlki, ontolojik güvenlik ve özgürlük bunalımı ve ontolojik yabancılaşma. İkincisi, epistemolojik bunalım. Çünkü artık "akıl, bilim ve ilerleme” denklemi epistemoloji olarak yürüyebilen bir denklem değildir ve Aydınlanma felsefesinin bu temel önermeleri sarsıntı geçiriyor. Üçüncüsü, mekanizma ve ahlak dengesizliğinde kendini gösteren aksiyolojik bunalım. Mekanizmayla ahlak arasında bağlantı kurulmadan mekanizma kendi ahlakını üretir, derseniz, bu mekanizma mutlaka tiranlı üretir. Eğer insanoğlunun özünde sahip olduğu normatif değerlerle sosyal mekanizmaları 
irtibatlandırmazsanız, bizatihi mekanizma problemi çözemez ve nitekim çözemiyor. Dördüncüsü, ekolojik denge yok olmuştur; ve beşincisi, kültürel çoğulculuk problemi bunalımı. (Davutoğlu, 2002, s. 8)

Tam da burada, bu beş bunalım noktasında (ontolojik, epistemolojik, aksiyolojik, ekolojik ve çoğulculuk) yüzyılın değerleri kötülük problemi ve şiddet açısından teolojik ya da seküler terimlerle ifade edilebilir olmakla birlikte esasen dünyanın bir bütün olarak anlaşılabilirliği hakkında bir soruna dönüşmüştür.

Yüzyılımızda ahlakın ve siyasetin önemli problem alanlarından olan kötülük ve şiddet özellikle bireysel ve toplumsal açıdan hukukun, iktidarın kavramsal yapısını ve pratiğini belirlemektedir. Tarihte kötülük ve şiddet insanın doğası ve eylemleri açısından ahlakın problemi olarak ve toplumsal düzende iktidarın meşru kılınması açısından da siyasetin araçları olarak tezahür etmiştir. Özellikle 21.yüzyılda ahlakın problemi ve siyasetin aracı olarak kötülük ve şiddet ile medeniyet anlayışlarının patolojik bir ilişkiyle ilkesizleştirilmesine şahit oluyoruz. Fakat bir yandan siyaset aracilığıyla "demokratik hak" adına özgürlüğü paranteze alan edimlerin meşrulaştırma aracı olarak bir yandan da insanın bireysel doğası ve toplumsal ilişkilerini ahlak, siyaset ve din adına biçimlendirmenin aracı olarak bu ilkesizliğin tam kendisi ilke olarak sunulmaktadır. Bu çelişik durumda kötülüguün ve şiddetin eleştirisi üzerinden demokrasinin ahlakın problemi ve siyasetin aracı olduğunu söyleyebiliriz.

Kötülüğün ve şiddetin eleştirisi siyaset ve ahlak zemininde ele alındığında; kötülük ahlak bağlamında, teoloji, teodise ve etik alanlarında adalet-günah kavramı açısından ve şiddet ise siyaset bağlamında yasalar-hukuk ve ekonomi alanlarında adalet-suç kavramı açısından değerlendirilmelidir. Benjamin'in ifadesiyle, "bir şiddet eleştirisinin görevi, şiddetin hukuk ve adaletle ilişkisini ortaya koymaktır. Çünkü 'siyaset açısından' şiddet ve ahlak arasındaki ilişkinin çerçevesi, duygusal açıklamaları ve teodise tartışmalarını paranteze alarak hukuk ve adalet kavramları tarafından çizilir" (Çelebi, 2010, s. 19).

Kötülük ve şiddet ne sadece ahlakî ve metafizik alana ne de siyaset ve hukuk alanına aittir, her ikisi arasında bir bağ oluşturmuştur. Bu açıdan kötülük ve onu takip eden şiddet soru(n/s)una yıkıcıllğının yanı sıra yapıcı bir rolde yüklenebilir. ${ }^{1} \mathrm{Bu}$ sorunlara yönelmek, bütün yıkıcılıklarına rağmen özünde oluşunun-varlığının temelleri sarsılan bireye 'kendini', bedenini ve mekânını anlamlandırma fırsatı sunmaktadır diyebiliriz. Başka bir ifadeyle, kötülük ve şiddet insanın hem bireyselliği hem de toplumsallığı bağlamında "kişi/ben" oluşuyla yüzleşmesidir. Bu yüzleşme 
ya insanın yasalara, adalete ve düzene bakışının şekillendiği bir isyan eylemine ya da yaşanan şiddete rağmen barışçıl, pasif sivil hareketliliğe dönüşmüştür.

Bu noktada varolan-yaşanmış kötülüğün kaynağını Eagleton, Marksist gelenek çerçevesinde insanın ekonomik ilişkiler içinde yarattığı adaletsizlikte bulmaktadır. "İnsanlik tarihinin barbarlik ve cehaletle dolu olması, kismen sinıf toplumunun yarattığı yapay kaynak kıtlığından ve büyük kitlelere 'insan' adlandırmasının ve öneminin verilmemesindendir.” Ama insanın iyi mi kötü mü olduğu konusunda da sırf toplumsal şartlar merkeze alındığında bilinemezci bir tavır takınmaktadır: "İnsan ırkıyla ilgili güvenilir bir ahlakî yargıda bulunamayız zira onu iflah olmaz şartların dişında gözleme şansımız olmadı" (Eagleton, 2011, s. 109). Bu bağlamda Eagleton'a göre "kötülük ve şiddet, 'anlaşılmazdır', 'bağlamsızdır, şeytan insanın içindeyse yenilmezdir', 'metafiziktir', 'beden ve ruh arasındaki bir ayrımdır' ve 'ölümsüzdür', 'dinin hükümranlığının bittiği bir toplumda kalan tek aşkınlıktır', 'tamamen sapkındır', 'korkunç bir içsel eksiklikten kurtulmaya çalışan zalimliktir', 'yaşam ve ölüm arasına sıkışmış bir varoluş şeklidir', 'insan özgürlüğünün bir sonucudur."' (Eagleton, 2011, s. 24, 61, 110) Kötülük etik, metafizik, teolojik, psikolojik ve doğal boyutlarıyla göz önüne alındığında tarihsel süreçte yüzyılımızdaki kadar yıkıcı, insanın bütünlüğünü ve bilincini bozucu düzeyde açığa çıkmamıştır. Kısacası, aslında kötülük problemi ve şiddet böyle bir "yerde" (politik-ekonomik-sosyal-psikolojik mekanda) insan olma sorunuyla ilgilidir.

Peki, şiddetin doğası nasıl tanımlanır, başka bir ifadeyle şiddet nedir? Bu soru, literatürde fiziksel ve dolaylı şiddet ve bu ikisinin alt dalları olan özel ve kolektif şiddet sınıflaması üzerinden tanımlanmıştır. Fakat bizim buradaki sorumuz, literatürdeki anlamın ötesinde niyet-eylem ve doğa üçlemesi çerçevesinde şiddetin "ne"liği, yapısı ve temsilleri ve bu temsillerin iktidar düzleminde ekonomi politik-siyaset ve ahlak alanına nasıl yansıdığıdır.

Şiddet, Yves Michaud tarafından yapılan kapsamlı bir tanımlamayla şöyle açıklanmıştır: "Şiddet, bir karşılıklı ilişkiler ortamında taraflardan birinin veya birkaçının doğrudan veya dolaylı, toplu veya dağınık olarak, diğerlerinin veya birkaçının bedensel veya ahlak (moral, manevi) bütünlüğüne veya mallarına veya simgesel ve kültürel değerlerine, oranı ne olursa olsun zarar verecek şekilde davranması"dır (Michaud, 1991, s. 11). Başka bir ifadeyle, kötülükten farklı olarak şiddet insan doğasının bir niteliği değil; insanın bedensel ve zihinsel potansiyelini korku, travma ve tatmin edilmemiş ihtiyaçları karşısında kullanamamasından kaynaklanır, performatiftir (Galtung, 1969). Yüzyılımızda toplum, birey ve iktidar ilişkileri teknoloji, kitle iletişim araçları ve ekonomik pazar değiştiği için şiddetin temsili, ölçüsü ve boyutları da değişmiştir. Bu tanımla birlikte şiddet temsilini ve araçsallığını iktidar, demokrasi ve eylem bağlamında hem aktörü hem de nesnesi açısından tarihte 
karşılaşılan her olay ve olguda bir öncekiyle ilişkili fakat aynı zamanda değişen bir bağlamda yeniden kurmaktadır.

Şiddetin "ne"liği ve temsiline dair analizler neslin sürekliliği, ekonomik güç, üstünlük ve siyasi iktidar başlıklarından hareketle yapısal ve antropolojik kökenli yaklaşımlarca sınıflandırılmıştır. Sosyal biyologlar, sosyologlar, antropologlar, psikologlar ve siyaset teorisyenleri şiddeti, daha önce de belirttiğimiz gibi, ya insan doğasına içkin bir dürtü-duygu durumu olarak ya da toplumsal-tarihsel ilişkiler sürecinde dışsal bir olgu olarak fiziksel, psikolojik ve yapısal şiddet sınıflamasıyla tanımlamışlardır. Burada şiddetin ontolojik kökeni ya da tarihselliğinden çok temsiline yöneldiğimizde -ki bu köken tartışmaları bu aşamada kısırdöngü oluşturmaktadır- iktidar, demokrasi, insanın eylemlerinin tarihselliği ve yasalarla düzenleniş sürecinin 21. yüzyılın soru(n)larına 1şık tuttuğunu söyleyebiliriz. Bu bağlamda 21. yüzyılda düzen bozuculuk ve düzen koruyuculuk şiddetin iki yüzüdür. ${ }^{2}$ (Bæck, 2004) Şöyle ki, şiddet, iktidar siyasetinin aracı olarak bir açıdan strateji gerektiren eylemken diğer açıdan da yönetim-denetim noktasında araçtır. Şiddet, bireysel ve muhalif siyasetin, Marksist bir ifadeyle, karşı devrimin bir dinamosu olarak, ya barışçıl eylemleri önceleyen sivil itaatsizlikte ya da terör eylemlerinde farklı rasyonelleştirmelerle karşımızda durmaktadır. Bir açıdan da Marks'ın Das Kapital'de yaptığı şiddet tanımı bugünkü tartışmalarımızın, iktidar ve demokrasinin şiddetle ilişkisinin, şiddetin araçsallığının kısa ve net bir özetini sunmaktadır diyebiliriz. Balibar, Marks'ın şiddet tanımını şöyle aktarmaktadır: "Bağlarında yeni toplumları taşıyan tüm eski toplumların ebesi” (Balibar, 2014, s. 25). Engels, Marks'ın şiddeti, eski toplumların donuklaşmış, “ölmüş” ideolojilerinin ve kurumsal yapılarının parçalanması olarak tanımlamasını tarihte şiddetin devrimci rolü ve şiddetin araçsallaştırılması olarak açıklar ve böylece şiddete pozitif bir anlam yükler (Engels, 2014, s. 169-185). Fakat insanlık tarihinde yaşananlar dikkate alındığında aslında şiddet tek başına ne övülebilir ne de yerilebilir, ne kutsaldır ne de onur kırıcıdır. Şiddet ancak toplum birey ilişkisinde kime nasıl ne ürettiği ve ne kazandırdığına göre farklı anlamlandırılabilir. Bu aşamada da şiddet ile ilgili araştırmaların soracağı soru insanların doğasında ve eylemlerinde şiddetin nasıl bir role sahip olduğudur. Şiddet, insanın eylemlerinde toplumsal düzenin kontrol edilmesinde mi yoksa düzeni bozan terör eylemlerinde mi ortaya çıkar? Hangi eylemi şiddet olarak tanımlayacağımız sorusu şiddetin işlevsel açıdan ve simgesel düzlemde nasıl tanımlandığıyla doğrudan ilişkilidir.

2 Burada özellikle düzen kavramı üzerinde durmak gerekir. Çünkü sübjektif bir kavram olarak düzen hem aktörü hem de tabi olanlar açısında farklı anlam ve değere sahiptir. Düzen kurucu güç açısından doğru ve adil olarak tanımlanabilirken tabi olanlar açısından adil ve eşit olmayan olarak görülebilir. Fakat bu çalışmada düzenin şiddet bağlamında bu iki yönüne sadece işaret edeceğiz. 
Bu noktada, benzer sorular ve yaklaşımlar ışığında ahlakın problemi ve siyasetin aracı olarak kötülük ve şiddet arasındaki ilişki, "İnsanın varolduğu her mekânda şiddet çeşitli görünüşleriyle vardır." yargısından hareketle hem insanın eylemlerine içkinliği hem de eylemin kendisi içinliği bağlamında incelenmelidir.

\section{Ahlak Problemi Olarak İnsanın Doğasında ve Eylemlerinde Kötülük ve Şiddet}

Şiddetin "ne"liğini konu edinen araştırmanın seyri tarihte kendini açan şiddetin temsillerini ve insan doğasının bu noktadaki yapısal rolünü incelemeye doğru şekillenmektedir. Erken modern dönemde Hobbes'la apaçık bir form kazanan insan doğasının yıkıcılığına dair kabuller 19. yüzyılda felsefi antropoloji çalışmalarıyla ve özellikle Freud'la birlikte, insan doğasının mı, eylemlerinin mi, yoksa toplumsal belirlenmişliklerin mi yıkıcılığı oluşturduğu sorusu üzerinden tekrar tartışmaya açılmıştır. Tartışmanın merkezinde de insanın doğası ve inşa ettiği bütün ilişkiler ağındaki rolü ve anlamı hakkında soru(n)lar ve kabuller bulunmaktadır. Bu noktada Kant'in Dünya Yurttaşlığı Amacına Yönelik Genel Bir Tarih Düşüncesi adlı çalışmasının 3. Önermesine bakar isek, "... Doğa, bir hayvan türünün akıl sahibi olmasını, birey olarak ölümlü, tür olarak ölümsüz olan bu akıllı varlıklar sınıfının yeteneklerini yetkinleştirmesini istemiştir" (Kant, 2006). diyerek insanın diğer canlılardan farkını ortaya koyar ve 4. Önermesinde de insan doğasındaki çatışma noktalarından bahseder:

Yeteneklerin gelişmesini gerçekleştirmek için doğanın kullandığı araç toplumdaki antagonizmdir; öyle ki, sonunda bu antagonizm yasaya uygun bir düzenin sebebi olur. Burada antagonizm ile, insanların toplum dışı toplumsallığını, yani bir toplum olma eğilimlerini, ama bu eğilimin de toplumu hep parçalamayı tehdit eden sürekli bir dirençle bağlantısını anlıyorum. Bu yeteneğin kökünü insan doğasında bulduğu apaçıktır (Kant, 2006).

18. yüzyıla kadar kötülük ve şiddet doğal, metafizik ve teolojik nedensellik üzerinden tanımlanırken Kant'la birlikte bireyin tercih ve sorumluluğundan hareketle niyet ve eylem ilişkisi üzerinden tanımlanır. Kant'ın 4. Önermesinde belirttiği gibi, insanın türsel ve bireysel yönleri insan doğasının ve eylemlerinin toplumsal ilişkiler ağı içinde açıklanması birçok açıdan çatışma noktası oluşturmuştur. Kant, Aydınlanma aklının gücünün ve insan doğasının yıkıcılığının yapıcı bir eyleme dönüşmesi için yönetici erki ve yasaları gerekli görmektedir: “...Üstelik, akıllı bir yaratık olarak herkesin özgürlüğüne sınır çekecek bir yasayı istese bile, gene de bencil hayvansal eğilimleri, yapabildiği yerde kendisini bu yasanın dışında saymaya sürükler onu. Kendi iradesini kıran, evrensel, geçerli olan ve 'herkesi özgür kılan bir iradeye onu boyun eğmeye zorlayacak' bir yöneticiye ihtiyacı vardır" (Kant, 2006). 
19. yüzyılda insan doğası ve insanın toplumsallığı hakkındaki tartışmaların merkezinde tanrısal yargıların, iktidar söylemlerinin ve ahlak-değer ilişkilerinin çatışmaları yer almıştır. İnsanın doğasını statik ve katı biçimde sınıflandırarak "birey”, "kişi” ve "öteki” karşıtlığı üreten bir sistemin şiddetle doğrudan ilişkisi birçok farklı tartışmanın konusu olmuştur. Bu tartışmaların teorik çerçevesi Ortodoks Marksist, psikanalist ve liberal kapitalist yaklaşımlar tarafından biçimlendirilmiştir. Fakat bu yaklaşımlar, insanın doğası ve toplumsallığı konusunda ortaya çıkan sorunlara çözüm getirmek yerine onları mekanikleştiren, sorunları çoğaltan ve süreci kaosa, çöküşe götüren başka tartışmaların zeminini hazırlamıştır. Bu tartışmaların ortasında kalan ve yüzyılımızda "öznenin sonunu" ilan eden "insan" hangi insandır? İnsanın, aydınlanmış modern bireyin (kadının iktidar olan erkek akılla mücadelesi, siyahın iktidar olan beyazla mücadelesi, yoksulun iktidar olan varsilla mücadelesi) kendisiyle hesaplaşması, toplumsal yapı açısından ahlak ve demokrasi bağlamında, tanrıyla ilişkisi açısından da teoloji ve teodise bağlamında bir "son" çağrısı olarak tanımlanabilir mi? Ve bu durum insanın doğasında ve eylemlerinde şiddeti "karanlığın yüreği” olarak dönüştürücü, devindirici güç olarak tanımlama imkânı sunar mı?

\section{Ínsanın Doğası: "Homo homini lupus"? ya da "Imago Dei”?}

Yaşayan, çalışan, konuşan sosyal varlık olarak insanın doğasına ve varoluşuna dair soru(n)lar düşünce tarihinin kadim, fakat canlı soru(n)larıdır. İnsanın doğayla ve tanrıyla kurduğu ilişki aynılık-farklılık kategorisinin yanı sıra çift kutupluluğu açısından da gündemde olmuştur. İnsan hem tür içinde hem de tür dışında öncelikle hayatta kalmak ve varlığını sürdürebilmek için daha sonra da yönetmek ve düzen yaratmak için kimi zaman bir araç ve kimi zamanda bir amaç olarak şiddete başvurmuştur. Başvurulan bu şiddetin kökeni "Bizzat insanın kendi doğasında mıdır yoksa öğrenilmiş bir tutum mudur?” sorusunun cevabı birçok farklı yaklaşım tarafından temellendirilmeye çalışılmıştır. Fakat bu süreçte şiddetin kullanımı, şiddeti insan doğasının kurucu bir niteliğiymiş gibi göstermiştir. Bu yaklaşım ise insanın eylemlerinde ortaya çıkan şiddetin kökeninin insanın doğasından mı yoksa kurmuş olduğu kurumsal yapılardan mı kaynaklandığı sorusunu tekrar ahlakın, psikolojinin ve dinin gündemine taşımıştır.

Şiddetin kaynağı, niteliği ve araçsallığı şiddet eleştirilerinin merkezine taşınarak sadece insan doğası değil aynı zamanda insanın inşa ettiği kurumların yapısı da soru konusu olmuştur. Şiddetin kaynağı nedir? Gerçekten insanın doğasından kaynaklanmıyorsa inşa ettiği kurumsal yapılardan mı gelir? 
Şiddetin insanın doğasından kaynaklandığ1 iddiası insanın beşer yönünü ve tarihsel, kültürel yönünü merkeze alan iki farklı yaklaşımla temellendirilmeye çalışılmıştır. İnsanın beşer yönünü (biyo-fizyolojisi) merkeze alan evrimci yaklaşımın ve psikanalizin yargılarında şiddet, içgüdülerin, dürtülerin ve arzunun kaynağı olarak insan doğasına, beşerliğine içkindir. Darwin Türlerin Kökeni, Freud Uygarlığın Huzursuzluğu ve Fromm İnsandaki Yıkıcılığın Kökenleri adlı çalışmalarında içgüdülerden ve temel ihtiyaçlardan hareketle şiddetin kökenini insanın beşerliğinde aramışlardır. Doğada varolan diğer canlıların davranışlarını ve etki-tepki süreçlerinin nedenselliğini anlamak ve insan türüyle ortaklığını belirlemekle elde edilen nedir? İnsanın beşer yönüyle (biyo-fizyolojisiyle) varolanlar arasında, ekosistemdeki varlık zincirinde bir yere sahip olduğunu göstermek araştırmacıya nasıl bir argüman sunar? Dönemin kozmoloji, teoloji ve iktidar konularında ortaya atılan önermeleri incelendiğinde aslında bu kabul kartezyen özne eleştirisidir, rasyonelliğinin kutsanmasına karşı eleştirilerin başlangıcıdır. İnsanın yüceltildiği yerden düşürülmesinin, kutsallığından arındırılmasının ve var olanlar zincirinde "sıradan bir oluşa" indirgenmesinin öncelendiğini görmekteyiz. Dolayısıyla, şiddetin insanın saldırgan doğasından kaynaklandığı iddiasının tek başına şiddet temsillerinin ve tarihte ortaya çıkan şiddetin ne olduğunun anlaşılması için geçerli olduğunu ama yeterli olmadığını söyleyebiliriz.

Şiddetin kaynağı hakkında ortaya atılan diğer kabul ise şudur: "İnsanın saldırgan doğasının yanı sıra hem kendine hem de kendi dışındaki özgür olan/olmayan her şeye uyguladiğı, doğrudan veyahut da dolaylı şiddet kurumlar aracılığıyla inşa edilen kültür, devlet ve ekonomi politikten kaynaklanır.” Bu yaklaşım özellikle Hobbes'un Leviathan, Machiavelli'in Hükümdar, Hegel'in Tarihte Akıl, John Stuart Mill'in Özgürlük Üstüne, Marks ve Engels'in Tarihte Zor'un Rolü adlı çalışmalarıyla temellendirilmiştir. Burada şiddetin kaynağı, insanın beşerliğinin yanı sıra ya da özellikle dışında insanın kurmuş olduğu düzende -iktidar ve mutluluk anlayışındaaranmiştır.

Machiavelli Hükümdar'ında insanların, yaratılıştan kötü oldukları için sevilen kişilerin şiddetinden çok korkulan kişilerin şiddetinden çekindiklerini, bu nedenle hükümdarın egemenliğini sürdürebilmek için sevgi bağlarından ziyade korku ve ceza ilişkisinde toplumsal hayvan olan insanı birlik-beraberlik içinde tutabileceğini ifade eder (Machiavelli, 2008, s. 64). Machiavelli'nin bu yarg1sı ve Hobbes'un "İnsan insanın kurdudur" yargısı "Imago Dei” olarak yeryüzünde bulunan insanın kendi doğasının tözsel yıkıcılığına vurgu yaparak maskelenen şiddeti apaçık kılmaktadır. Hobbes çizgisinde seyreden tarihselci kabule göre, insan şimdi ve burada, doğa, 
toplum ve tanrı ilişkisinde ortaya çıkan vahşi, hatta kana susamış bir karaktere sahiptir. O bu karakterini kurumlara da yansıtır. Fakat bu açıklamaların yanı sıra 20. yüzyılda yeni tarihselci çizgi için insanın saldırgan karakteri özsel değil tarihsel koşul ve toplumsal yapılarla-kurumlarla bağlıdır. Onun bu karakteri gelecekte farklı kurumsal koşullar altında değiştirilebilir veya oldukça farklı, daha barışçıl bir biçim alabilir (Keane, 1998, s. 106). Keane'in şiddeti merkeze alan bu sınıflamasına felsefi antropoloji bağlamında baktığımızda, insan doğasını "var olma ve bilme" ile 'eylem ve değer' düzleminde tanımlarız. Var olma ve bilme düzlemindeki tanım mekanizm, canlılık ve araçsallık çerçevesinde bir yanıyla rasyonalizme ve bir yanıyla da empirizme dayanan analitik söylem sınırları içindedir. Eylem ve değer düzlemindeki tanım ise tarih, kültür ve metafizik çerçevesinde bir yanıyla tarihselciliğe bir yanıyla da idealizme dayanan romantik söylem arasındaki bağlantılar-farklar üzerinden açıklanır.

Felsefi antropolojinin ya da siyaset bilimin tanımları çerçevesinde genel hatlarıyla insan doğasının oldukça kompleks ve fakat bir o kadar da çelişik varoluşa sahip olmakla birlikte ontolojik boşlukların, anlam sorunlarının ve günahların da kaynağ1, nedeni ve kimi zaman da sonucu olduğu görülmektedir. İnsan doğasının doğa, kültür, yaratıcı etken, genetik kod katmanları üzerinde temellendirilen bu çift kutuplu çelişkili yönü günahın, ontolojik boşluğun ve hiçliğin sınırlarında kim'liğini inşa eden 21. yüzyıl insanının serüveninin de merkezinde durmaktadır. Bir yandan "İnsanın doğası yoktur, tarihi vardır." derken bir yandan da bilimin gölgesinde genetik çalışmalarla insanın doğasının şifrelerini ve hatta tanrıya inanma geninin genetik kodda yerini tespit etmeye çalışmak şiddetin ve kötülügüun simgeleştirilmesidir.

Şeytanın meleği ve iblisi kendi kişiliğinde birleştirmesi ve birlikte taşıması gibi kötülük de meleksiliği içerir. Kötülüğün meleksi yönü sonsuzluğun, anlamlılı̆̆ın peşinde koşar ama aynı zamanda şeytani yönü anlamsızlığın ve faniliğin peşinde koşar. Kötülüğün bu iki yüzü birbiriyle yakından ilgilidir ve insanın doğasında bu iki yüz bir arada tecessüs etmektedir (Eagleton, 2011, s. 69-70).

Bu yaklaşımla, 21. yüzyılda, Aydınlanmanın gerçekliğe, akla, anlama yaptığı analitik, mekanik ve matematikleştiren vurguyu tersine çevirerek duyuları, duyguları, geçiciliği ve kısmen anlamsızlığı ön plana çıkaran; fakat bu noktada da boşluğun, anlamsızlığın ve "cehennemin, lanetlilerin" kaderini paylaşan; salt formdan oluşan insanın varoluş durumuyla karşı karşıyayız. Alexsandre Pope insanın bu trajik yönünü çok daha erken bir dönemde fark etmiş ve İnsan Üzerine Deneme'sinin ünlü pasajında şöyle açılklamıştır: 
Orta bir devletin bu kıstağına yerleştirilmiş,

Bilgeliği müphem, büyüklüğü görkemsiz bir varlık: ...

(İnsan) kararsızdır; harekete geçmekle sükûnet arasında,

Bilmez tanrılığa mı soyunmalı, hayvan mı olmalı yoksa,

Zorlanmakta zihniyle bedeni arasında tercih yapmakta,

Ölmek için mi doğmakta, hata etmek için mi akıl yürütmekte;

Fark yok böyle bir akılla az düşünmesi ya da

Çok düşünmesi arasında, her ikisi de aynı şeye varmakta:

Düşünce kaos içerisinde, tutku bir karmaşa baştan ayağ1;...

Yegâne hakiki hüküm, boy vermekte sonsuz hata arasında:

Dünyanın şaşaası, alaycılığı ve taşıdığı muamma! (Toulmin, 2002, s. 160)

Yüzyılımızda insan, hiçlik, günah, suç, şiddet ve kötünün karşında tanrıyla kavgalı, tanrıya rağmen yıkıcı-kıyıcı iktidar geliştiren ve intiharı tanrının iradesini yok sayan bir özgürlük eylemi olarak kabul eden bir kimlikle çağına seslenmektedir. Bu açıdan bakıldığında insanın kötülük ve şiddet karşısındaki çelişik durumu, kendisi için korku ve kaçınma bağlamında ürettiği kurumlar (tarih-toplum-devlet) aracılığıyla -Hatta onlar tarafından- kendisini yok etmesinin simgesel olarak trajedisidir. Modern insan, Aydınlanma'nın çağrısı doğrultusunda ergin olma yolunda medenileştikçe Imago Dei (tanrının yeryüzünde yansıması) olmaktan uzaklaşıp iktidar ve üretici güç olarak bir tür insan yiyiciliğinin, insan kıyıcıllğının başka bir ifadeyle sömürgeciliğin kurumsal temsilini oluşturmuştur. Bu durum modern insan için bir haz ilkesine dönüşmüş ve savaş, toplumsal refah, "sosyal adalet", "medenilik" adları altında çeşitli maskelerle simgesel şiddet üzerinden meşrulaştırılmıştır. Başka bir ifadeyle, tanrının ölümü insanı, inşa ettiği kurumlar ve hukuk aracilığıyla başka insanlar üzerine hâkim kılmıştır. 21. yüzyılda artık yasalar, yasa koyucular ve yasanın koruyucuları metafizik zemin kaymasıyla değişime uğramıştır.

Ahlak, siyaset ve antropoloji insanı farklı soru(n)lar üzerinden ele alıyor olsa bile insanın, kötülük ve şiddetle ilişkisinde her üçünde de ortak soru(n), insan doğasını aşan iktidarın kendisi ve iktidarın meşrulaştırıcı aracı ekonomi politiktir. Bunun yanı sıra, tanımlanmaya çalışılan insan doğasının eril bir doğa olup olmadığı da tartı̧̧maya açılmıştır 20. yüzyılda. Bu soru(n)ları, insan doğasını ister eril ister dişil olarak tanımlasınlar ontolojik açıdan "kutsanmışlığına", "lanetlenmişliğine" ve "saldırganlığına" toplumsal açıdan sömürgeleştirilmesine, üretim-tüketim sarkacında kurulan varlığına vurgu yaparak ele almışlardır. Bu noktada insan için kötülük, şiddet ve demokrasi teolojik ve/veya seküler yasalar açısından hesaplaşılması gereken olgular olmaktan çok, "hak" sayılan meşru "insanlık durumu"na dönüşmüştür. 
Bu süreç göstermektedir insan doğası ifadesiyle artık sadece insanın beşerliği değil belirli bir tarihin ve kültürün öznesi olan insanın tarihselliği vurgulanmaktadır. Bu noktada da tür olarak insan doğası hakkında temellendirmeler yapan yaklaşımlar onun bu gerçekliğiyle çelişmektedir ve onu apolitik ve tarihsiz kılmaktadır. İnsan salt bir beşer değil belirli bir tarihin, kültürün ve dahi kurumların etkisiyle bizzat tarihte var olan, etik ve estetik değerler üretendir. Bu çerçevede de şiddetin kaynağ1 salt insan doğasının beşerliğinde değil bu beşerlik etkisi üzerinden kurulan tarihselliği ve kurumsallığı bağlamında açıklanmalıdır. Peki, bu değerler içinde, insanın eylemleri açısından tarihte şiddetin rolü nedir?

\section{İnsanın Eylemi: Vita Activa ve Kötülük}

Bu yüzyılın özneleri olarak büyük bir yalnızlık ve yabancılık hissiyle kötülük ve şiddetin sadece yüzyılımızın ve gelecek yüzyılların çözümsüz sorunu olduğunu, içinde bulunduğumuz dünyanın var olabilecek en kötü dünya olduğunu düşünürüz. Fakat biliyoruz ki, bu problem insanlık tarihi kadar eskidir, süreç içinde yüzyılları aşıp günümüzde farklı bağlamlarda (metafizik, doğal, ahlaki) yeni pratiklerle açığa çıkarak özgün-özerk bir biçim almaktadır; her defasında başka bir maskeyle ilk defay"mış gibi” görünmektedir. Bu problemin eleştirisinin, analizinin ve değerlendirilmesinin totoloji oluşturmadan sürdürülebilmesi için tartışma, insan eylemlerinin toplumla ilişkisi içinde ahlak, hukuk, sanat ve ekonomi alanlarıyla ele alınmalıdır.

Antikçağda vita activa (eyleyen, eylemi başlatan ve davet eden) olarak insan, bios politikos'un (polis-kent yaşamının) içindedir. Arendt buradan hareketle insanı, kamusal ve özel alanda iş, emek, eylem bağlamında bu dünyada insan olmak'lık açısindan tanımlar (Arendt, 1994, s. 26-27). Yani insan vita activa olarak, iyi, üretici ve olumlu değer inşa eden eylemleriyle kötü, tüketen ve şiddet oluşturan "huzur-suz" eylemleri arasındaki diyalektik üzerinden tanımlanabilir. Vita activa olarak insanın eylemlerinde kötülük ve şiddet nasıl aşikâr olur? "Eyleyen, eylemde bulunan başka varlıklar arasında hareket ettiği ve onlarla ilişkide bulunduğu için hiçbir zaman sadece fail değil, her zaman ve aynı zamanda bir kurbandır da" (Arendt, 1994, s. 261). Bu noktada, kötülük ve şiddet 'kurban', uygulayıcı ve tanık arasında araçsal bir ilişkide ortaya çıkan fiziksel ve simgesel zarar verme, yok etme ya da işlevsizleştirme vita activa olarak karşımıza çıkar. Bu açıdan insan, şiddete maruz kalan aynı zamanda da şiddeti uygulayandır.

Ardından Arendt'in vurguladı̆̆ı gibi kötülük ve şiddet algısı, özellikle İkinci Dünya Savaşı sonrasında küreselleşen dünyada var olan bütün kültürleri etkileyecek şekilde radikal bir değişime uğrar. Ona göre kötülük ve şiddet, suç-suçlu ek- 
seninde hostis generis humani 'bütün insanlığa düşman olan' yeni bir suçlu türü” nün eylem ve etkinliğidir. Bu yeni suçlu türü "suçlarını, yanlış yaptığını bilmesini ya da hissetmesini hemen hemen imkânsız kılan koşullar altında" hareket ettiği için yapadurduğu eylemler, şeytani kötülükten çok kötülügün sıradanlaşması-gündelik hayat içinde ideolojilerden ve etik değerlerden uzak ekonomik ilişkiler ağında kurulan sıradan bir "işe" dönüşmüştür. Adorno, kötülük problemini ve şiddeti "Auschwitz'den sonra şiir yazmak barbarlıktır." diyerek gündeme getirirken, Arendt Avrupa'da savaş sonrası entelektüel yaşamın temel meselesi olarak tanımlar: "Orada kabullenemeyeceğimiz şeyler oldu, hiçbirimizin kabullenemeyeceği." Arendt kötülük ve şiddet problemi açısından İkinci Dünya Savaşı'yla yaşanan bu değişimi politik ve ekonomik açıdan da sınıflandırmıştır. Çünkü artık kötülük ve şiddet mistik, mitik, büyüsel söylemlerden arındırılarak gündelik hayatın, vita activa'nın/ bios politikos'un bir parçasına dönüşmüştür. Burada Arendt ve Adorno çizgisi İkinci Dünya Savaşını ve özellikle Auschwitz'i insanın çaresizliğinin, acizliğinin ve iktidarının sonucu olarak "tepkilerimiz" in de "hiç bu kadar zayıf olmadığı" ifadesiyle trajikleştirmiştir. Başka bir ifadeyle, kötülük problemi ve şiddetin araçsallaşması Reform, Erken Modernite, Aydınlanma, Pozitivizm, Modernite ve ardından yaşanan postmoderniteyle, 1916'da patlak veren küresel emperyalist savaşla, Bolşevik Devrimiyle, nasyonal sosyalizmin yükselişiyle, ekonomik krizlerle ve soykırımlarla (Eagleton, 2013, s. 33) bir "bozuluşun" hikâyesi olarak karşımıza çıkmaktadır. Bu bozuluş hem ontolojik hem etik ve estetik bir durum olarak insanlık sahnesinde oynanan çok maskeli küresel oyunun yalnızca birkaç perdesini temsil etmektedir.

Oysa 21. yüzyılın varlık ve oluş şartları bağlamında insan için hem doğası hem de küreselleşmeyle şekillenen yönetici erk anlayışı sağlam zeminin ve güvenilir normların kaynağı olmaktan çıkmıştır. İkinci Dünya Savaşı́ndan sonra yaşanan katliamlar ve küresel düzeyde cereyan eden iktidar çatışmaları doğrudan bireysel olanı etkilemiştir. Bu süreçte ahlakî nihilizm güçlenerek kötülük ve şiddeti, postmodern dönemin mottosu da olan "Her şey meşrudur." kabulü ve "Orta sınıf medeniyeti postmodern dönemine ulaştığında günah moda olmuştur." (Eagleton, 2011, s. 108) iddiası çerçevesinde insan haklarının evrenselliği vurgusuyla pozitif hukukun sınırları bağlamında tartışma zeminine taşımıştır. Böylece kötülük ve şiddet, ahlakın problemine siyasetin de aracına dönüşmüştür.

Özetle, insanın eylemlerinde şiddet tarihin farklı dönemlerinde farklı temsil araçlarıyla görünür kılınmıştır. Başka bir ifadeyle, Reform ve Erken modern dönemden içinde yaşanılan yüzyıla kadar şiddet özellikle savaşlarda, kamu düzeninin bozulmasında, kadınların cadı ya da fahişe olarak etiketlenmesinde, toplumsal sınıfların radikalleşmesinde ya devletin denetiminde ya da bireysel olanda yazılı 
ve görsel malzemelerle, sokak gösterilerinden tiyatro sahnesinde, şiir-ağıt ve türkülerde görünür kılınmıştır (Ruff, 2011, s. 27-28). 19. yüzyıl sonrasında ise şiddet yine savaştan ama artık cephe savaşları değil kitlesel ölümlere neden olan yeni savaş teknolojileriyle donatılmış bir ordunun hâkim olduğu soğuk savaş üzerinden gündeme gelmektedir. Ayrıca edebiyat, sinema, televizyon, dijital oyunlar, mimari vb. alanlarda da kötülük ve şiddet hem anlamı genişletilerek hem de yıkıcılıkları güçlendirilerek görünür kılınmaktadır. Yüzyılımızda kötülüğün ve şiddetin nasıl bir temsil içinde kendilerini açacaklarını anlayabilmek için özellikle yeni insan, toplum ve devlet anlayışlarının iyi analiz edilmesi gerekmektedir.

\section{Siyasetin Aracı olarak Demokrasi Bağlamında Kötülük ve Şiddet}

Bir yönetim modeli olarak demokrasi, toplumsal ve bireysel çıkarları kolektif haklar bilinciyle açıklayabilen, makro ve mikro düzeyde özgürlükleri teminat altına alabilen ve çatışma noktalarında bireyi ve toplumu yöneten-yönetilen ilişkisinde ortak, çoğulcu çözümlerde birleştirebilen bir yönetim, yönetişim algısıyla inşa edilmektedir. Bir yönetişim modeli olarak demokrasinin nitelikli, iyi bir model olabilmesi için rejimin ve bireyin özgürlüklerinin karşılıklı güven çerçevesinde garanti altına alınmasına, özgürlüğün hem yasayla tesis edilmesine hem de bu yasanın kurumlar ve bireylerin karar alma ve eylem süreçlerinde koşulsuz olarak kullanılabilmesine bağl1dır (Ringen, 2009, s. 57-58). Bu demokrasi anlayışı siyasal kurumlar içinde üç ilkede kendini açığa çıkarır: İktidarın yönetilenlerin temel haklarını kabul etmesi, yöneticilerin edimlerinde toplumsal temsiliyeti öncelemesi ve yurttaşlık bilincinin geliştirilmesi (Touraine, 2010, s. 413). Bu üç ilke ise Derrida'nın yaklaşımıyla hukuk, şiddet ve adalet paradoksu oluşturmaktadır. Çünkü evrenselliğini her koşul altında geçerli kılması zorunlu olan hukuk adalet aracılığıyla bireyselliği paranteze alarak şiddeti meşru kılmaktadır (Çelebi, 2010, s. 48-49). Birçok yüzü ve simgesi olan kötülüğün ve şiddetin çağımızda en açık görünen maskesi demokrasiyle şekillendirilmiştir.

Yüzyılımızda ise demokrasi anlam daralması yaşayarak kamu düzeninin korunmasını, düzene karşı çıkan ötekilerin temizlenmesini kanun perdesinde şiddet üzerinden sağlamaktadır. Başka bir ifadeyle, demokratik düzenler kimi zaman şiddeti 'karşı şiddet'le denetim altına almak ve hukukun bir uygulaması olarak kabul etmekle demokrasi tanım ve içeriğini bozmaktadır. Oysa en derin anlamıyla demokrasi, birbirinden farklı ahlak kurallarını kabul eden ve yaşayan insan toplulukları içinde ve arasında gücü eşitçe bölüştürüp açıkça denetlemenin şiddetsiz bir aracıdır (Keane, 2010, s. 9). Burada Benjamin'in hukuk ve ahlak kesişiminde şiddetin yapıs1 ve eleştirisiyle ilgili sormuş olduğu kritik sorulardan biri gündeme gelmektedir: "Eğer bir şiddet ilkesel düzeyde adil amaçlara hizmet eden bir araçsa, onu ahlakî 
olarak tanımlayabilir miyiz?" (Çelebi, 2010, s. 19) Hegel ve Benjamin, şiddetin hakların ve bireyin iradesinin ihlali olarak kabul edildiğinde, her ne kadar adil olursa olsun, ahlakî olarak değerlendirilemeyeceğini söylerler (Hegel, 2015, s. 93-94). Tam da bu noktada iktidar ilişkilerinde yasa yapıcılık, başka bir ifadeyle, doğal hukuk ile pozitif hukuk arasındaki yaptırım gündeme gelmektedir. Doğal hukukun araçsallığ1 ile pozitif hukukun amaçsallığı arasındaki çatışma iktidarın doğası üzerinden demokrasi ve küresel dünyanın devlet ve birey algısını demokrasi ve ekonomi-politik bağlamında şiddetle ilişkisi açısından sorgulamaya taşıyor. Doğal hukuk ve pozitif hukukun şiddetle ilişkisini Benjamin kurucu hukuk ve tutucu hukuk bağlamında ele alarak şiddetin pozitif hukuk aracılığıyla devlet içinde temellendirildiğini iddia eder. Hukuk, demokrasi ve insan hakları çerçevesinde toplumda şiddeti meşru kılmıştır. Burada Foucault'ün Hükûmetlere karşı, İnsan Hakları başlıklı yazısının son cümlesi demokrasinin aracı olarak şiddet anlayışı açısından kritik bir noktaya işaret etmektedir: "Bireylerin iradesi hükûmetlerin tekelinde tutmaya çalıştığı bir gerçekliğin içine dâhil edilmelidir ve bu tekel her gün adım adım sökülüp alınmalıdir" (Foucault, 2000, s. 290). Bu bağlamda soru(n)lar da şu noktada gündeme gelmektedir: "Şiddeti haklı kılacak meşru bir ilke var mıdır? Böyle bir ilke meşruiyetini yasalardan mı yoksa ahlaktan $\mathrm{m} ı$ almaktadır? Şiddetin meşruiyeti şiddetin temsillerinde mi aranmalıdır? Ya da başkalarından gelen şiddeti püskürtmek veya ortadan kaldırmak için kendi şiddet araçlarını geliştirip kullanmalı mı kullanmamalı mı, ne zaman veya nasıl kullanmalı?" vb. Bu soru(n)lar felsefî açıdan Hegel, Benjamin ve Arendt çizgisinde şiddet-suç-ceza ve hukuk tanımlarından hareketle teorik çerçevede kurum-eylem ilişkisi açısından; siyaset bilimi ve kurumlar açısından da şiddetin neliği, araçsallı̆̆ı, simgeselliği ve amaçsallığı tarafından açıklanabilir. İlk açıllamada her ne sebeple olursa olsun, hangi kutsal amaca hizmet ediyor olursa olsun şiddet, ahlak ve siyaset açısından ne doğrudan bir araç ne de bir amaç olabilir.

Bu doğrultuda Hegel açısından baktığımızda, şiddetin hukukla temellendirilen ontolojisini suç ve ceza bağlamında ele alabiliriz. Şiddet, Hegel'e göre, iki şekilde ahlakın ve hukukun konusudur. İlki, irade üzerine uygulanan haksız fiildir. "İrade ancak bir mevcudiyete sahip olduğu ölçüde İde veya gerçek özgürlük olduğuna ve büründüğü mevcudiyet özgürlüğ̈̈n varlı̆̆ını oluşturduğuna göre, şiddet, kendi kavramı içinde kendisini yok eder. ... şiddetin kendi kendisini yok etmesi, bu kavramsal prensip, realite aleminde bir şiddetin başka bir şiddet tarafından yok edilmesinde kendini gösterir. Bu durumda ise şiddet birinci şiddeti ortadan kaldıran ikinci şiddet olarak haklı olur" (Hegel, 2015, s. 113). İkincisi ise, soyut hukuk bir şiddet hukukudur, özgürlüğün mevcudiyetinin korunması bir dış eylem olarak birinci şiddeti ortadan kaldıran ikinci bir şiddet olur. Bu çerçevede de haksız eylemler olarak tanımlanır. Çünkü şiddetin kendi kendisini yok etmesi gerçeklik dünya- 
sında şiddetin ceza aracılığıyla, başka bir şiddetle, yok edilmesi olarak somutlaşır. Bu durumda da cezayla ortaya çıkan ikinci şiddet, şiddeti araçsal kılar ve "haklı ve zorunlu" eyleme dönüştürür (Hegel, 2015, s. 114). ${ }^{3}$ Oysa bu kabul edilebilir değildir. Arendt'in bu noktada şiddetin dönüşümü-araçsallaşması hakkındaki ifadesi bu durumun neden kabul edilemez olduğunu da açılklar: “...Araçlar amaçlara galebe çalar. Amaçlara hızlı ulaşılmazsa, sonuç yalnızca bozgun değil, daha kötüsü siyasal alana şiddetin girişi olacaktır. ... her eylem gibi şiddetin pratiği de dünyayı değiştirir; ama en olası değişim, daha şiddetli bir dünya doğrultusundadır" (Arendt, 2014, s. 89-91). Burada Benjamin şiddetin araçsallığını, şiddeti, suç ve ceza ilişkisinde iki boyutlu tanımlayarak gösterir. Ona göre ilk olarak şiddet, yasa koyucusu, yaratıc1s1, koruyucusunun kökeni ve kaynakları sorunu açısından şiddettir. İkincisi ise, etik ve estetik bir eylem olarak toplum, birey ve devlet düzleminde temsili sorunu açısından şiddettir. Benjamin'in bu tanımlamasıyla kaynak ve temsil sorunu bağlamında ikinci bir sorun olarak şiddetin araçsallığıyla karşı karşıya kalırız. Şiddetin araçsallığı ise bizi doğrudan Arendt'in açıklamalarına yönlendirir. Ona göre, “doğası gereği araçsal olan şiddet, kendini haklılaştırması beklenen amaçlara ulaşmakta etkin olduğu ölçüde rasyoneldir... ve ancak kısa vadeli amaçlar güttüğü zaman rasyonel kalabilir" (Arendt, 2014, s. 88-89). İktidar ilişkilerinin yapısı ve rolü şiddetin varlığını, yöntemini değiştirdiği gibi, şiddet de iktidar ilişkilerini yıkabilir, tahrif edebilir. Arendt bu ilişkinin özellikle amaç-araç bağlamında kurulduğunu söyleyerek şiddetin her türlü görünümünün yıkıcılığını vurgular. "İktidar bir amacın aracı olmanın ötesinde, fiiliyatta bir insan topluluğunun amaç-araç terimleriyle düşünmesini ve eylemesini mümkün kılan koşulun ta kendisidir" (Arendt, 2014, s. 57). Hegel, Benjamin ve Arendt çizgisinde tanımlanan şiddetin ontolojisini ve araçsallığını, Balibar şöyle bir tarihsel çerçeve içinde ele alır: İster devrimci isterse kapitalist-liberal siyaset hüküm sürüyor olsun şiddete karşı şiddet, hukuka karşı hukuk ve şiddete karşı hukuk ve hukuka karşı şiddet durumları tüm siyasi yapılanmalarda birbirini ya içerir ya da yadsır (Balibar, 2014, s. 20-24).

Peki, bu düzlemde demokrasinin aracı olarak şiddet nasıl bir işleve sahiptir? Bu soruya kurum ve eylem ilişkisi çerçevesinde yöneldiğimizde Keane'nin kurumsal açıklama modelinden ilki, orta düzey rejim kurumları akla gelir. Bu kurumlarda sınırlı ve/veya geniş çapta ortaya çıkan şiddetin temelde bir devletin veya bir sosyo-ekonomik sistemin tekil, tarihsel örgütlenme ilkelerinden kaynaklandığını savunur. İkincisi ise makro düzey jeopolitik kurumlardır ve şiddetin nihai köklerinin, 
uluslararası sistemin sürekli olarak merkezi olmayan yapısında aranması gerektiğini savunur (Keane, 2010). Bu modellerin ilkinden hareket ettiğimizde şunu söyleyebiliriz: Küresel yapılanmayı paranteze alarak özgürlük ve demokrasinin ihdası adına bireyin ve toplumun yaşadığı kötülük ve şiddet, iktidar mücadelesinde tüm yaşananlar ötekileştirmeyle ya da sömürgeleştirmeyle birlikte belirli bir toplumsal yapıya ait mikro düzey ekonomi politik arayışının "inşâ̂” sonucudur. Özellikle sömürgeleştirmeyle birlikte siyasetin aracı olan şiddet, Marks ve Engels'e göre "mülksüzleştirenlerin mülksüzleştirilmesi” sürecinde ortaya çıkan yıkıcı güçler ve üretici güçler arasındaki diyalektiktir. Bu diyalektik, siyaset açısından dinamik bir eylem durumuna neden olmakla birlikte yasalar ve ahlak açısından belirsizlik ve çatışma getirmektir. Bu durum hem evrensel insan hakları açısından hem de hukukun "hakların koruyucusu" olduğu kabulü açısından nasıl "onaylanacaktır"-"olumlanacaktır"? Burada hakların koruyucusu olarak pozitif hukukun yasa yapıcılı̆̆1-yaratıcılığ1 temsili ve referansları açısından sorun oluşturmaktadır. Belirtilen ikinci modelden hareket ettiğimizde ise uluslararası hukukun yapısı ve milletlerin talepleri arasında dengenin-adaletin nasıl sağlanacağı konusunda yaşanan "şiddetle" yüz yüze gelinmektedir. Bu şiddetin tam kalbinde ise Robinson Crusoe'un Cuma'yla ilişkisinde ve adayı tanımlayışıyla simgeleştirilen modern küresel devletlerin Batı dışı toplumları sömürgeleştirme anlayışı bulunmaktadır. Fanon'a göre sömürgeleştirilen, mülksüzleştirilen toplumun uyguladığ1 şiddet aslında sömürgecinin araçsallaştırdığı şiddetten kaynaklanır (Fanon, 2007). Başka bir ifadeyle, sömürge toplumunun uyguladığı şiddetin kaynağında sömürgecinin bizatihi kendisi bulunmaktadır ve buradaki şiddet eleştirilecek ise bütünüyle sömürgecinin eleştirilmesi gerekir. Bu açıdan bakıldığında şiddet sömürgeleştirilen toplumun kendini var edebilmesi için "meşru" bir araca dönüşmüştür. Burada hem sömürge hem de sömürgeleştirilen toplum için şiddet ve iktidar birbirinin mütemmim cüzü gibi değerlendirildiği için şiddet meşru bir araç olarak görülmektedir. Oysa şiddet ve iktidar birbirinin karşıtıdır; şiddet ancak iktidarla araçsal bir ilişki kurabilir ama iktidarın meşru aracı olarak değil.

Şiddetin adil yargıların, demokratik girişimlerin ve meşru hak arayışlarının sonucunda ortaya çıması ve uygulanması hukuk ve siyaset bağlamında araçsallığını sorunlu fakat bir hak arayışı olarak "kabul edilebilir" temele oturtmuştur. Bu durumun hukukta, siyasette ve ekonomide bir karşılığı olmakla birlikte ahlak açısından kabul edilebilir değildir. Çünkü şiddetin her türlü kullanımı hem öznesinin hem de nesnesinin değer düzenini altüst eder, ahlakını bozar. Bu noktada Hegel'in ve Schopenhauer'un suç-ceza ilişkisini Becceria'nın ceza hukukuna referansla özellikle suçlu açısından ele almalarının arkasında yatan ahlaki kaygı anlaşılmaktadır. Hegel'e göre, suçluya verilen ceza yalnızca kendiliğinden haklı olmakla kalmaz aynı 
zamanda suçlunun eyleminde dışa vurulan iradesinin de hakkını vermektir. "Suç işleyene verilen ceza, onun bizzat kendi içinde oluşmuş bir haktır. Eylem akıllı bir varlıktan geldiğine göre, içinde evrensellik vaz edilen bir kanunu da taşır. Suçlu, bu kanunu, işlediği fiilde kendisi için kabul etmiştir" (Hegel, 2015, s. 117). Schopenhauer ise cezanın suçla doğru orantılı olması gereğinden hareket eder ama cezanın suçun kefareti olarak değil, suçlunun eylemiyle mütekabiliyet içermesi gerektiğini söyler. Önlenecek eylemden kaynaklanacak kötülük ne kadar büyükse ceza da suçlunun iradesi de o kadar güçlü olmalıdır (Schopenhauer, 2009, s. 90). Örneğin, idam cezasının hakların korunması açısından uygulanması gerektiğini Hegel üzeri kapalı, Schopenhauer ise açıktan söyler. Şiddet, adalet ve ceza arasındaki ilişki ahlak ve siyaset açısından eylemin amacıyla doğrudan ilişkilidir. Kanun koyucular ve uygulayıcı kurumlar bu doğrudanlığı dikkate almalıdırlar. ${ }^{4}$

\section{İnsanın Aydınlığında Demokrasinin Karanlığı}

İktidarın demokrasiyle hedeflediği özgür düşünmek ve eylemek: İktidarların ilkelerini de etkileyecek ve kendi çıkarlarına-beklentilerine uygun olarak insanı araçsallaştıran, onu tüketim nesnesi kılan durumları perdeleyerek makineden derece farkıyla ayrılan insanın "onuruna” uygun davranmak düşüncesini toplumda yerleştirebilmektir. 21. yüzyılda demokrasi pozitif hukuk aracılığıyla iktidarın zayıfları "medenileştirmek" ve "demokratik olmak" adına onlara uyguladıkları şiddet düzenine dönüşmektedir. ${ }^{5}$ W. Churchill 1974'te yaptığı, konuşmada demokrasiyi tarihte denenmiş diğer yönetimlerin dışında en kötüsü olarak tanımlamıştır. Bunun arkasında yatan neden, bizce, siyasetin çıkarları doğrultusunda toplumları ezmek ve sömürmek için şiddetin araçsallaştırılmasını demokrasiyle perdelemesidir. Tam da bu durum şiddete karşı örtük bir şiddeti beraberinde getirmektedir. Özünde demokrasinin amacı yurttaşlara hizmet etmektir, kendini araçsallaştırarak demokratik olmak değildir (Ringen, 2009, s. 44). Bu durum dikkate alındığında, A. Giddens Modernliğin Eleştirisi adlı kitabında demokrasi tarihinin halkın egemenliği ile insan hakları ilkesinin giderek birbirinden ayrılışının tarihi olarak tanımlamasının haklı temelleri görülmektedir.

Burada özellikle A.Eichmann'ın yargılanma süreci ve Arendt'in yorumunu birlikte değerlendirdiğimiz, cezayı eylemle doğrudan ilişkilendiren Hegel ve Schopenhauer ahlak ve siyaset ilişkisini nasıl yorumladıklarını görebiliriz.

5 Burada özellikle şuna dikkate edilmelidir: Gewalt kavramının hem şiddet hem de egemen iktidarın düzeni anlamına gelmesi konunun farklı yönlerini vurgular. Kavramın bu iki boyutu anlamını genişletmekle birlikte belirsizliği de beraberinde getirmektedir. 
Baumann, Modernite ve Holocaust isimli eserinde demokrasi ve şiddet ilişkisinde modern medeniyetin şiddetten arınmış halinin bir yanılsama olduğundan bahseder. Asıl olan, demokrasi aracılığıyla şiddetin yeni alanlara yayılıp gözden ırak k1lınmasıdır. Demokrasi bireylerin bireyselliğini inşa ettikleri politik zeminin kurucu unsuru olmakla birlikte, iktidar ilişkileri açısından karanlık bir yapıdadır. Burada demokrasi ve medenileşme bağlantısı şiddetin araçsallığını pekiştirmekte, devlet ve devletler üstü sivil yapılanmalarını biçimlendirmektedir. Başka bir ifadeyle, silahsızlanma ve güdümlü sivil yapılanmalar, kurumlar aracıllğılyla bireylerin pasifleştirilmesi ve zorunlu barış ortamlarının sağlanması açısından "demokrasinin" araçsallaştırılmasıdır. Bu edimlerin arkasında yatan kabul ise insanın saldırganlığıdır. Fakat şiddetin kaynağının ne olduğuna dair yapılan araştırmalar göstermiştir ki şiddeti sadece tümel ve insan doğasına-insanın beşerliğine gömülü bir kavram olarak almak yanıltıcıdır. Çünkü şiddet aynı zamanda tarihle, kurumlarla, olgu ve olaylarla görülen ve özellikle arızi bir durumdur. Bu noktada demokrasi bir tür özgürleşme (özgürleştirme) modeli olarak sunulduğunda sömürgeleştirme faaliyeti olarak şiddetle iş birliği içinde karanlık yüzünü aşikâr kılmaktadır.

\section{Demokrasinin Korunması Aşkına Simgesel Şiddetin Araçsallığı}

18. yüzyıl sonu ve 19. yüzyıl ilk çeyreği arasında evrimci, ilerlemeci bakış açısıyla medenileşildikçe, sivil toplum inşa edildikçe şiddetten ve barbarlıktan uzaklaşıldığ kabul edilmekteydi. Oysa 19. yüzyılın son çeyreğinde yaşananlar göstermektedir ki medenileşildikçe iktidar pozitif hukukun ve anti şiddet yaklaşımının korunması adına şiddeti araçsallaştırmıştır. Özellikle bu yüzyıllar ve sonrasında şiddetin psikolojinin bir kavramı olarak ele alınmasından ziyade bireysel, toplumsal ve kurumsal yıkıcılık için siyasetin ve ahlakın önemli bir aracı olduğu görülmektedir. Şiddet uygulamak sadece bir sosyal ilişkiye içkin, yıkıcı bir nitelik katmak değil aynı zamanda toplumsal ve tanrısal bir yıkım da katmaktır. C. Wright Mills, "Tüm siyaset iktidar mücadelesinden ibarettir, iktidarın nihai biçimi de şiddettir" der ve özellikle Max Weber'in de etkisiyle iktidar için, (Arendt, 2014, s. 45) bireyin birey ve toplum üzerinde meşru olduğu iddia edilen şiddet araçlarıyla egemenlik kurması olarak Hobbesvari bir tanımlama yapar. Oysa görülmektedir ki bu tanımlamayla, demokrasi adına şiddettin araçsallı̆̆ı ve kötülügün ahlakın problemi oluşu insanın medenileşme sürecini tam olarak açıklayamamaktadır.

Toplumun bireylerle ve "öteki" toplumlarla ilişkilerinin düzenlenmesi doğrultusunda amaçlarına ulaşmak için despotça yöntemlere başvuran bir demokrasi hareketiyle uzun süre demokratik kalması düşünülemez. Çünkü seçtiği araçlar amaçlarını yok eder (Keane, 1998, s. 97). Fakat demokrasi ve barış adına karşı karşıya kalınan 
"şiddet", devlet eliyle icra edildiğinde toplum nezdinde meşru ve "barışç" bir imge oluşturur. Bu noktada Hobbes'un Leviathan'ında, devlet çatışma ve savaşı önleyen ya da daha doğru bir ifadeyle, ortak çıkarlar için yönlendiren bir role sahiptir: "Devlet olmadıkça herkes herkese karşı daima savaşır haldedir" (Hobbes, 2007, s. 94). Machiavelli'nin Hükümdar'ında ise iktidar için her yolun meşruluğu iddiasıyla başlayan "şiddete karşı şiddet”" kabulü 21. yüzyıl çağdaş devlet kurgusunun dayandığı temel tutamak noktalarını destekler. Bunun yanı sıra Hobbes'un herkesin herkesle savaşını, insanın türselliğinde ve doğal eşitliğinde temellendiren anlayışı 21. yüzyılda simgesel şiddet aracılığılla iktidar güçler tarafından kullanılmıştır, eşit olmayan bir savaş ortamı yaratılmıştır. Bu da siyaset ve ahlak bağlamında kötülüğün ve şiddetin kırılma noktasını temsil etmektedir. Örneğin, 1945 sonrası toplumsal demokrasinin genişlemesiyle bağımsız kurumların çoğalması, şeffaf olmadığı için ayrıcalığı kolaylaştıran girift bir dolambaç, idari ve adli açıdan bilinmez bir labirent yaratarak demokrasi perdesinde örtük şiddete alan açmıştır (Dauve \& Nesic, 2012, s. 135). Kurumlar yoluyla uygulanan örtük şiddet, şiddetin simgeselleşmesi anlamında önemli, siyasetin klasik dönemdeki kabullerini ters düz etmektedir. Çünkü şiddet bu yolla sıradanlaştırılıp örtük hale getirilerek günlük yaşamın bir rutinine ve özellikle eşitsizliğe dönüştürülmüştür. Toplumsal demokrasiyle yönetenleri ve yönetilenleri birleştiren ve böylece birilerinin diğerlerinin üzerindeki iktidarlarını göreceleştiren kesin ve kurumlaşmış bir ilişki tehdit oluşturmaktadır (Dauve \& Nesic, 2012, s. 87).

Şiddet ve karşı şiddet durumlarına ilişkin üretilen çözümler tüm şiddet araçlarının yetkisini "akılcı ve tarafsız" kabul edilen merkezî bir iktidar elinde toplama ve bu şekilde meşru kılma amacını taşımaktadır. Yüzyılımızda savaşlar sonucunda gelinen küresel ekonomi ve yenidünya düzenleri bu amaç doğrultusunda tarafsız ve evrensel bir iktidarın kurulması imkânını azaltmaktadır. Başka bir ifadeyle, liberal hoşgörü ve ifade özgürlüğü adı altında yapılanlar ortalığın, rızaya ve ahlaki değerlere dayalı liberal bir toplum idealiyle böylesine bağdaşmayan o kan ve istırap görüntüleriyle dolup taşmasını kolaylaştırmaktadır (Hobsbawm, 2006, s. 244).

\section{Deus mortus est! Ne yapmalı? "Yaşasın Küreselleşme ve Şiddet”!}

Arendt'in ve Adorno'nun dediği gibi, "Batı için Auschwitz kötülüğün ve şiddetin zirvesidir. Bundan sonra insanlık tarihinde böylesi ve ötesi bir şiddet görül(e)mez." yargısının son 20 yıldır yaşananlar göz önünde bulundurulduğunda eksik kaldığı söylenmelidir. Yüzyılımızda şiddetin “yapısı” öznenin doğasına içkinliği ve dahi öznenin başkasına yönlendirdiği nesneleştirme eylemindeki aşkınlığı ve aşırılığı nedeniyle ne Freud'un ne Marks'ın ne de Lacan'ın insanın dürtüleri, ikinci doğası, fantazileri ve kötücüllüğü açıklamalarıyla yorumlanabilir. Tarihin, medeniyetlerin, tanrının 
ölümü karşısında "özne" olarak insan, şiddet aracilığıyla ontolojik, epistemolojik ve aksiyolojik bunalımları açısından teorik alanda bir dönüşüm, devrim yaşamaktayken endüstriyelleşme ile birlikte şehirlerin ve özellikle küresel şehirlerin yapılandırılması çerçevesinde de ekolojik ve kültürel çoğulculuk bunalımı yaşamaktadır.

İkinci Dünya Savaşı'ndan sonra Amerika Birleşik Devletleri, dünyanın tamamının ya da büyük bir kısmının Birleşik Devletler ekonomisine hizmet edecek şekilde organize edilmesini hatta haritalanmasını planlamıştı. Bu planın silahı ise "demokrasi ve özgürlük"tür (Chomsky, 1997, s. 12-14). 20. yüzyllda ülkeleri egemenlik altına almak için istikrarsızlaştırıp ardından da "istikrarın" getirilmesi amacıyla demokrasiyi silah olarak kullanmak bir yönetim stratejisi olmuştur. Bu doğrultuda küresel kapitalizm, dünya üzerinde şiddeti antisemitist, islamofobik katliamları, karşı kültürlere yönelik korku, öteki siyasetini biçimlendiren eylemlerden ve temsillerden arındırmak amacıyla özgürleştirmek ve demokratikleştirme aracılığıyla yaymıştır. 21. yüzyılın başından itibaren demokrasinin araçsallığında islamofobi üzerinden hem dinî hem etnik hem de politik gruplara karşı korku iktidarıyla şiddetin meşrulaştırıldığı söylenmelidir. Özellikle islamofobi perdesi arkasında Avrupa'nın tam da merkezinde yaşanan ve etnik-ırk yapısına göre biçimlendirilecek bir demokrasi için yapılan Srebrenitsa Katliamı, evrenselleşme söylemiyle hareket eden orta düzey rejim kurumlarınca gerçekleştirilen bir "etnik temizliktir". Bu çerçevede, hem Avrupa merkezli siyasetin aktörlerince hem de "İslam adına cihad" çağrısıyla özel olarak yetiştirilmiş menşei belli olmayan IŞiD tarafından bir başka etnopolitik temizlik ise Gazze'de, Misır'da, Yemen'de, Suriye'de, Ruanda'da, ABD'nin bazı bölgelerinde ve Ukrayna'da yaşananlardır. Bunlar güç (şiddet) yoluyla zorunlu kılınmış barış eylemleridir. Bu "savunma amaçlı" etnik temizlik, "barış eylemi" olarak evrensel demokrasi, yurttaş hakları ve toplumların haklarının korunması adına gerçekleştirilen insan için ve fakat insana rağmen demokrasi adına uygulanan şiddetin örtük somutlaşmasıdır (Neocleous, 2011, s. 312). Bu yaşananlar her kriz çağında olduğu gibi, insanı kendi içine dönüp bireysel olarak varoluşunun anlamını sormaya yönlendirmiştir. Bu süreçte ilk ve öncelikli olarak, şiddet aktörünün nesnesiyle olan özsel-içsel bağının tarihte dışsallaşan şiddet tarafından gölgede bırakılmasıyla başlayan ve insanoğlunun döktüğü kana ve yaşadığı şiddete seyirci kalan tanrının ölümünün ilan edilmesiyle devam eden bir çöküşle yüzleşmektedir insan: "TANRI ÖLDÜ... (Deus mortus est)", peki şimdi ne olacak?

Baudrillard'ın açıklaması ve kesişimsellik kuramı açısından öznenin bu süreçte ne yapacağı ve dönüşümü incelendiğinde ırk-etnik yapı ve cinsiyet merkezli toplumsal kimliklerin ayrıştırıcilığının kötülük ve şiddet bağlamında siyasetin bir aracına dönüştürüldüğü görülmektedir. Şimdi bu çerçevede 21. yüzyılda yaşananları sınıfladığımızda dört temel soru ve bu sorunlar çerçevesinde şekillenen dönüşümle 
karşı karşıya kalınmıştır diyebiliriz. Bunlardan ilk üçü insanın “özne” ve "birey” olarak ontolojisinin değiştiğini gösterirken dördüncüsü ise bütün bu değişimin içinde toplumsal ve siyasal yapının değişimini konu edinmiştir. Bu soruların ilki, beyinle bilgisayarın denkliği iddialarında somutlaşan Sibernetik devrim ve insanın temel sorusu “Bir insan mıyım yoksa yapay zekâ ile programlanmış bir makine mi?”, değişen kozmoloji ve yeni fizik tanımlamalar insanın var olduğu zaman ve mekân algısını da değiştirmiştir. Bununla bağlantılı olarak şekillenen ikinci soru, doğanın kodlarıyla insanın kodları arasındaki bağlantıda ortaya çıkan Genetik devrim ve insanın varoluşunun biyolojik temellerine dair sorusu: "Bir insan mııım yoksa sanal bir klon mu?" ve üçüncüsü, "kim"liğin toplumsal ve biyo-fizyolojik yönü üzerinden Cinsel devrim ve insanın üstesinden gelemeyeceği ve varoluşuna yabancılaştıran şu soru ortaya çıkar: "Biyolojim kimliğimi belirler mi yani erkek ya da kadın oluşum benim tercihim olabilir mi?”. Dördüncüsü, tüm diğer devrimlerin öncüsü olan Siyasal ve Toplumsal devrim ve iktidar bağlamında insanı kendi özgürlük ve irade kullanımı kapsamında "tanrı ya da iktidar iradesi karşısında insan iradesinin nerede olduğu, temelde neyi istediği ve insanın kendisinden neyi bekleme hakkı olduğu" sorularını kendine sormaya yöneltmiştir (Bauldrillard, 2010, s. 29). Baudrillard'ın tanımında bu son aşamayla insan, kendi kendisinin yargıcı olmuştur, hatta insanın klasik anlamda özne oluşuyla şekillenen "ben"inin sonunu ilan etmesi istenmiştir. Ayrıca kesişimsellik kuramının renk, etnik aidiyet, toplumsal cinsiyetlerin eşit haklar uğruna ayrıştırıcı söylemi insanın tümel metafizik bir kavram "insan" ve tür olarak tanımlanmasının imkânsızlığı üzerine kurulmuştur. Bu noktada insan "Ben kimim?!” ve "Hangi iktidar benim "kim" olduğumu belirleme hak ve yetkisine sahiptir?" sorularıyla yüz yüze kalmıştır. Tam da bu yüzyılda bu soruların temelinde tanrının ölümü, iktidar referanslarıyla tanımlanan toplumun bireysel çıkarlar açısından farklı olanın yok edicilikle ve eşitsizlikle suçlanması ve bütün bunların temelinde de bireyin varoluşu ve kimliği hakkındaki derin sorgulaması bulunmaktadır (Ceran Karataş, 2015). Özellikle yüzyılımızda sinema filmlerinde ve edebiyat metinlerinde şiddetin simgeselliği, sıradanlığı ve "ötekiliği” siyaset, din ve teknoloji bağlamında insanın bu ontolojik dönüşümünü görünür-düşünülür ve konuşulur kılmıştır.

\section{Sonuç}

"21. yüzyıl insanlık tarihinin görülmedik şiddet, kıyım ve soykırımlarına şahit oldu" diyoruz fakat bin yılların birikimi olan ve karşımızda duran bu yüzyılı hazırlayan kötülük ve şiddet nasıl açıklanacaktır? 21. yüzyılda bütün bu olup bitenler şiddetin engellenmesi için düşünülen tarafsız iktidar anlayışının ve barış temelli pasif siyasetin (Gandivari) gerekli ama yetersiz olduğunu bir kez daha göster- 
miştir. Yüzyılımızda şiddet, kötülük ve demokrasi bir yandan ahlakın (teodisenin) tanrıyı öldüren başkaldırısına diğer yandan da siyasetin günlük yaşamı sıradanlaştıran, tek biçimlileştiren "etkinliğine" dönüşmüştür. Burada tek değişen, haber kaynaklarının ve öldürme tekniklerinin-teknolojilerinin apaçık, bilinir ve gösterilir olmasıdır. "Erdem ve ihsan doğasıyla insan"ın yerine geçen "kan dökücü-saldırgan doğasıyla insan" kabulü insanlığın ilerleme ve medeniyetler tarihinin yazarı olduğu kadar felaketler tarihinin de yazarıdır. "Kötülük ve şiddet olmasaydı iyilik ve iktidarın düzenleyici yönü olmazdı-anlaşılamazdı." patolojisi ise insanın kaderini, yazgısını örten sır perdesidir ve asıl trajedi de bu noktada başlamaktadır. Kutsalların ve insanın ürettiği ne varsa yine insan tarafından ölüm ilanıyla çağın şahitliğine birakılmaktadır.

Araçsallık bağlamında birey varlığını ve devlet iktidarını "özgürlük" çerçevesinde sürdürebilmek için demokrasiye ihtiyaç duymaktadır. Fakat sorun tam da burada ortaya çıkmaktadır, Bauman'ın da belirttiği gibi Moderniteyle birlikte demokrasi klasik anlamda yurttaş merkezli bir demokrasi değildir artık; elit yönetim erkinin temsilinde ve rejimin devamlllığ esasında şekillenen statik bir demokrasidir. Yurttaşların arayışı kimi zaman şiddetin ikincilliğinde kimi zaman da kötülüğün iktidarında "iyi demokrasi" arayışına evrilmiştir. Yeni tür demokrasilerle birlikte demokrasi hâlâ siyaset mekanizmalarını, rejimi ve iktidarı "iyi" işletme olarak tanımlanmaya devam ederse 21. yüzyıl, siyaset felsefeleri açısından farklılıkların, şehir-devletlerinin, etno-politik çeşitlenmelerin merkezîleşmenin çeperlere yayıldığ ve radikal kötülük ve sıradan şiddet aracıllğıyla yeniden şekillendiği distopyalara gebedir. Bu noktada sorun şiddeti araçsallaştıran "Demokrasi nedir ve demokrasi ne işe yarar?" sorularının yanı sıra özellikle ve öncelikle "demokrasinin imkânı" çerçevesinde şekillenmektedir. Mümkün demokrasilerin en iyisi olan demokrasi için öncelikle siyaset dilinin değiştirilmesi gerekmektedir. Değer merkezli kamu etiği demokrasinin dili ve imkânı için kuşatıcı bir anlam küresi oluşturacaktır. Böylece yurttaşlar, birey merkezli sürdürülebilir ekonomik refahı, "güvenlik" teminatını, kültür ve sanat değerlerinin üretimini evrensel tek bir form yerine yerelin ve evrenselin bir araya getirildiği özelleşen, dinamik ve yenilenebilir bir demokraside temsil edilme imkânı bulacaktır (Zolo, 1992, s. 177-181).

$\mathrm{Bu}$ noktada incelenen metinler ve tartışma konuları dikkate alındığında 21. yüzyılda demokrasinin referanslarının yöntem ve tanım açısından değiştirilmesi gerektiğini söylemeliyiz. Tarihsel süreç içinde yaşanan praksisler siyasetin kötülügü, şiddeti ve demokrasiyi araçsallaştırarak dönüşümü hedeflediklerini ama her defasında insan kıyıcılığının arttığını ve demokrasinin karanlık içinde kaldığını göstermiştir. Demokrasinin belirleyiciliğinde ulus devletler, ahlak ve siyaset bağ- 
lamında kötülügü ve şiddeti araç olmaktan çıkarabilmek ve küresel sorunlar karş1sında özellikle dünya askeri düzeninin genişlemesi, savaşın endüstrileşmesi ve nükleer silahların varlığı-edinilmesi (Giddens, 2005, s. 437) karşısında etkili ve yapıcı bir eleştiri süreci ve şiddetsizlik teorisi geliştirmelidirler. Bu noktada özellikle kamu etiği ve adalet gibi farklı referanslar üzerinden yapılacak olan yeniden-yeni demokrasi tanımı, yaşanılan bunalımları ve karşılaşılan şiddeti çözüp denetleyebilecek şekilde genişletilmelidir. Başka bir ifadeyle, artık demokrasi, iktidarın rejimi ve yurttaşları demokratikleştirmek için değil; yurttaşların insani gelişim göstergelerine göre daha iyi bir hayata sahip olabilmeleri için çalışmak olmalıdır (Karstedt, 2006). Demokrasi iktidarın meşrulaştırılmasının statik, evrensel, tekçi bir aracı değil; yurttaşların refah düzeyine göre kurulan, tarihî-kültürel kodlara göre yenilenen çift yönlü dinamik bir süreç olmalıdır. Demokrasinin bu çerçevede şu ilkeleri merkeze alan kurumsal yapılandırılmaya ihtiyacı vardır: Seçimle belirlenmiş memurluk; özgür, adil ve kısa periyodlarda yapılan seçimler; ifade özgürlügü̈; alternatif bilgilenme kaynakları; kurumsal özerklik; vatandaşların karar alma mekanizmalarına dahil edilmesi (Dahl, 2001, s. 88). Demokrasi böylece yurttaşların özgürlük, güvenlik ve refah taleplerini şekillendirmek için bir araç değil bu taleplere göre şekillendirilecek, düzenlenecek bir model ve kurumsal bir strateji olacaktır. Yüzylımızda demokrasi, kamu etiği olarak, şiddeti şiddetsizliğe ve şiddete neden olan eylemleri barış̧̧l eylemlere dönüştürecek karşılıklı güven ve nezaket merkezli bir politik model olmalıdir. 


\title{
Evil and Violence in the Context of Ethics, Politics and Democracy
}

\author{
Yaylagül Ceran Karataş
}

In this article, we will discuss human nature and acts with regard to evil, violence, and democracy and whether they are inherent to our nature or not on ethics and political grounds. Then we follow the question which is "what kind of roles evil and violence have in the liberation of the human being?" Following on from that, we will inquire into evil and violence under the umbrella of disputed "particular democracy" on the grounds of epistemology, ethics, historical roles, and nature in the 15th and 21st century in Continental Europe. First of all, we consider that evil and violence are the instruments which are legitimized via democracy, how we can correlate ethics, politics, and democracy. In other words, what is the role of evil and violence in history? Then within this context, how we can define democracy, evil, and violence in relation to ethics and politics? While researching these questions, we will follow Arendt's and Benjamin's critics of violence and also categorize evil and violence using Keane's arguments. Our argument is that there is a way which we can find in non violent resistance within a new understanding of democracy in the public ethics and politics.

\section{Ontology of Evil, Violence, and Democarcy}

In basic ethics and politics, the history of philosophy is a kind of panorama which puts forward the notion of searching how to become a human being using dialectics of good versus bad, crime and punishment or justice versus cruelty.

Both Aristotle's idea of "zoon politikon" and Hobbes's idea of "homo homini lupus" are based on two perspectives of the human being, which are rational per- 
fection and aggressive instinct, in the power of enlightenment. In this context, evil and violence are tools and problems for ethics and politics in the 21st century. Acts (such as, frightening, killing, penalizing, suppression, revolt, rebellion, and suicide etc.) are issues to think about in view of Ethics and Politics.

Considering evil and violence as the instruments that legitimize themselves through democracy, on the other hand these are symbolized by immanent and devastating essences in social relations, effecting how we can correlate power and democracy. In other words, what is the role of evil and violence in History? Within this context, how can we define democracy, evil, violence, and power in relation to the problems of ethics and politics? In this article, we will discuss human nature and human action with regard to evil, violence, and democracy which are implicit and also which are transcendent according to ethics and politics grounds. Then we follow the question which is "what kind of role does evil and violence have in the process of liberating the human being?"After all, we will make an inquiry into evil and violence under the umbrella of disputed "specific democracy" on the grounds of ontology, ethics, historical roles, and nature in the 21st century.

This century was the age of decadence and one characterized by the descent of the confidence of the Enlightenment and rationality and also classifiering theoratical frames. In other words, this age was called the end of every theoratical building: the end of the history, the end of the ideology, the end of the philosophy, the end of the subject. Davutoğlu found these crisiss into five points with regards to understanding what happened in the history of the Western World. These five points are ontological confidence, liberty and ontological alienation; epistemological crisis; ethical crisis; ecological crisis, and pluralism. In these five crisises points (ontological, epistemological, ethics, ecological and pluralism) the values of this age have been transformed by the problem of understanding the unity of the world.

Benjamin said "mission of violence criticises puts forward to relation between law and justice in violence. When framing the relation of violence and ethics leave aside emotional explanations and theodicy then go towards law and justice."

Evil and violence are about not only ethical and metaphscial sides but also politics and law. Thus it can be said that evil and violence are mixed blessings, namely they have constructive and destructive sides but we mostly focus on how they are destructive as political tools or ethical behaviors. Following this way, evil and violence are confrontations for human beings for both inviduals and societies. This confrontation has two opposite faces. One side calls to individual revolt for law, system, and juridical. The other calls for peaceful and non-violent actions. 
Evil did not have the power to destroy both the unity of the human being and his/her relation with his/her body and mind in terms of his-her ethical, metaphysical, theological, psychological, and natural dimensions until these ages. In the 19th century, there was a discussion at the center of theological, political power, and ethics-value relations, about whether human beings have an innert nature or are shaped by their socail circumstance. This discussion was caused by the static and strict separation of human nature as an "individuum" or a "person/self", or 'the other' triggried violence and evil based on ethics and politics. The theoretical frame of this discussion as drawen by Orthodox Marxism, Psychoanalyisc, and Liberal Capitalism but these theoretical frames did not solve the sepration of human unity and caused mechanic, caotic debates and accelerated to collapse. How can we set up relations between evil, violence and democracy based on ethics and politics?

In accordance with, Y. Michaud's description of vilence: "Violence is injurious behavior which destroys the wholeness of the body or mind of another by any means." On the other hand, violence needs to be defined more rationally and realistically with a less normative flourish. It is better understood as direct but unwanted physical interference by groups and / or individuals with the bodies of others, who are consequently made to suffer a series of effects ranging from shock, speechlessness, mental torment, night-mares, bruises, scratches, swellings, or headache through to broken bones, heart attacks, loss of body parts, or death. So as we see violence can take many forms.

In other words, violence is different from evil in terms of the qualifications of a human being. It is loosing the use of the body and mind potentials on the contrary of fairs, trauma and dissatisfaction. Violence is a performative that is to say it is not regular and repeatable but creating in each single case. Arendt and Adorno said that "Auschwitz was the peak of evil and violence in the West." It is true that it was one of the worst things in human history, but not the only tragic case. We saw far worse than this on several other occasions, such as the Bosina, Khojaly massacre. In this age, it is believed that there is only one way to explain the structure of violence through immanent human nature (second nature, phantasy, and malevolent) such as Freud, and Lacan. But evil and violence are also related to the problems of becoming a human being on the grounds of political, economic, social, and psyhological realities. For this reason, we need to find new perspectives on understanding relations between evil, violence and democracy in regards to ethics and politics. In other words, the theme evil, violence and democracy will clearly not be approached without a philosophical discussion which should aim to profit not only form the contemporary epistemological debate, but also from the contributions which are offered by antropological, sociological, and political research. 
In this way, first of all this question should follow that is how to define particularly our way via democracy: "Can individual or collective actors within these societies nonetheless seize such institutions and 'realize' democracy?" We should consider the possibility that democracy may be an unintended consequence of far different and often far less emotional processes than we customarily associate with the transition to democarcy. It is at this point, we should seek new references to democracy in terms of themodality and description in the 21st century. In the praxis is shown the political aims to transmute via instrumentalized evil, violence and democracy. However it is always faced with rising cruelty and darkened democracy. From this century, violence has legitimized fears of islamophobia and brinkmanship by means of instrumentalized democracy in etnic, political and religious groups. In the light of democarcy, national states should organize critical processes and non-violent actions to counter war industry, nuclear weapons and the enlargement of the World military order.

Society can not be democratic using despotic tools. Democratic consensus within the organizational circuits of societies is envisaged by both classical and contemporary ethical theories as flowing from the bottom-up. In complex societies the legitimacy of political decisions is not based on a general criteria of a political or a juridical nature. In this age democracy should be a political model as public ethics which include mutual trust and courtesy. Thus by this model will violence be transformed into non-violent actions. A more directly political problem (in violence and law relations) emerges in the democratic governability of current societies. Thus new referances for democracy, based on public ethics and justice, could differentiate the crisses and violence. Democracy puts it differently democratization claims, then focuses on human development index.

Consequently, evil and violence have been essential components of human beings in the context of ethics, politics and democracy during this century. Not to define but to depict a new democracy based on public ethics, unity of human beings gains new perspectives of understanding.

\section{Kaynakça | References}

Arendt, H. (1994). İnsanlık Durumu. (B. S. Şener, Çev.) İstanbul: İletişim Yayınları.

Arendt, H. (2014). Şiddet Üzerine. (B. Peker, Çev.) İstanbul: İletişim Yayınları.

Bæck, A. (2004). Thinking Clearly about Violence. Philosophical Studies: An International Journal for Philosophy in the Analytic Tradition, 117, 219-230.

Balibar, E. (2014). Şiddet ve Medenilik. (S. Tamgüç, Çev.) İstanbul: İletişim Yayınları.

Bauldrillard, J. (2010). Kötülüğün Şefafı̆̆ı. (I. Ergüden, Çev.) İstanbul: Ayrıntı Yayınları. 


\section{The Journal of Humanity and Society}

Ceran Karataş, Y. (2015). İnsanın Kötülüğü ve Yalnızlığının Yazgısı. Lacivert Dergi, 9.

Chomsky, N. (1997). Demokratik İdeallerin Çöküşü. (C.Cerit, Çev.) İstanbul: Pınar Yayınları.

Çelebi, A. (2010). Şiddetin Eleştirisi Üzerine. (A. Çelebi, Ed.) İstanbul: Metis Yayınları.

Dahl, A. (2001). Demokrasi Üstüne. (B.Kadıoğlu, Çev.) Ankara: Pnoenix Yayınevi.

Dauve, G., \& Nesic, K. (2012). Demokrasinin Ötesinde. (İ.Kahraman, Çev.) İstanbul: Sel Yayıncılık.

Davutoğlu, A. (2002). Küresel Bunalım. İstanbul: Küre Yayınları.

Eagleton, T. (2011). Kötülük Üzerine Deneme. (Ş. Bezci, Çev.) İstanbul: İletişim Yayınları.

Eagleton, T. (2013). Hayatın Anlamı. (K. Tunca, Çev.) İstanbul: Ayrıntı Yayınları.

Engels, F. (2014). Tarihte Şiddetin Rolü. (O. Kunal, Çev.) İstanbul: YKY.

Fanon, F. (2007). Yeryüzünün Lanetlileri. (Ş. Süer, Çev.) İstanbul: Versus Yayınları.

Foucault, M. (2000). Özne ve İktidar. (I. Ergüden, Çev.) İstanbul: Ayrıntı Yayınları.

Galtung, J. (1969). Violence, Peace, and Peace Research. Journal of Peace Research , 6 (3), 167-191.

Giddens, A. (2005). Ulus Devlet ve Şiddet. (C. Atay, Çev.) İstanbul: Devin Yayıncılık.

Hegel, G. (2015). Hukuk Felsefesinin Prensipleri. (C. Karakaya, Çev.) İstanbul: Sümer Yayıncılık.

Hobbes. (2007). Leviathan. (S. Lim, Çev.) İstanbul: YKY.

Hobsbawm, E. (2006). Devrimciler. (H. Şenoğuz, Çev.) İstanbul: Agora Kitaplığı.

Kant, I. (2006). Dünya Yurttaşlı̆̆ Amacına Yönelik Genel Bir Tarih Düşüncesi. Ö. Doğan, \& G. Ateşoğlu (Ed.) Tarih Felsefesi içinde (s 30-47). Ankara: Doğu Batı Yayınları.

Karstedt, S. (2006). Democracy, Values, and Violence: Paradoxes, Tensions, and Comparative Advantages of Liberal Inclusion. Annals of the American Academy of Political and Social Science , 605, 50-81.

Keane, J. (1998). Şiddetin Uzun Yüzyılı. (B. Peker, Çev.) Ankara: Dost Yayınları.

Keane, J. (2010). Şiddet ve Demokrasi. (M. Üst, Çev.) Ankara: İmge Kitapevi.

Machiavelli, N. (2008). Hükümdar. (N. Adabağ, Çev.) İstanbul: Türkiye İş Bankası Kültür Yayınları.

Michaud, Y. (1991). Şiddet. (C. Mutlu, Çev.) İstanbul: İletişim Yayınları.

Ringen, S. (2009). Demokrasi Neye Yarar. (N. Elhüseyni, Çev.) İstanbul: YKY.

Ruff, J. (2011). Erken Modern Avrupa'da Şiddet (1500-1800). (D. Türkoğlu, Çev.) İstanbul: Boğaziçi Üniversitesi Yayinevi.

Schopenhauer, A. (2009). Hukuk, Ahlak ev Siyaset Üzerine. (A.Aydoğan, Çev.) İstanbul: Say Yayınları.

Sorel, G. (2002). Şiddet Üzerüne Düşünceler. (A.Hazaryan, Çev.) Ankara: Epos Yayınları.

Stewart, J., \& Strathern, A. (2002). Violence: Theory and Ethnography. London \& Newyork: Continuum.

Toulmin, S. (2002). Kozmopolis. (H. Arslan, Çev.) İstanbul: Paradigma Yayınları.

Touraine, A. (2010). Modernliğin Eleştirisi (7. Baskı). (H. Turan, Çev.) İstanbul: YKY.

Zolo, D. (1992). Demoracy and Complexity. USA: The Pennysylivania State University Press. 